\title{
骨 \\ THE VILLAGE GOVERNANCE MODEL THAT EMPOWERS COMMUNITIES IN INDONESIA'S BORDER AREAS
}

\author{
Rizca Yunike Putri \\ Study Program of Political Science, Social and Political Science Faculty \\ University of Wijaya Kusuma Surabaya \\ Email: rizcaputri.fisip@uwks.ac.id
}

\begin{abstract}
The problems that arise in relation to the implementation of village government are human resource capacity and institutional capacity in community empowerment. It is undeniable that villages in the Border have diversity in terms of the capacity of the village human resources and village institutions. For established villages, the implementation of the Village Law and the PP Village does not raise serious problems that can actually provide space for innovation to improve the welfare of rural communities. However, another story is that villages with minimal capacity certainly need efforts so that the village government is able to do better things for its people. Especially community empowerment for poverty alleviation through increasing income of poor families. By using qualitative research methods, supported by in-depth interviews in data collection and supporting sekounder data, this study provides an illustration of how village government empowered communities in villages as well as Indonesia's border areas.
\end{abstract}

Key Word : community empowerment, village government, border area 


\section{INTRODUCTION}

The policy regarding the Village as a product of the political process that the government deliberately made to solve a problem, of course has a set footing and objectives. In this era of globalization and reform, the existence of the Village has a platform to be protected and empowered so that it becomes strong, advanced, independent and democratic so that it can create a strong foundation in implementing governance and development into a just, prosperous, and prosperous society.

In the context of poverty alleviation programs in Border Districts, various programs for fostering human resources in rural areas need to be designed and at the same time improve the level of welfare. This is intended to better equate the access of the entire community to the development process and its results. There needs to be special attention to the poor who are left behind and have not been fortunate compared to other groups. The handling of poverty in principle is the solution of problems related to the condition of natural resources that are not profitable and the low access of poor groups to the opportunities available.

The problem of the diversity of the conditions of the poor in Border Districts requires an initial data collection that is expected to solve important initial problems identified such as (a) Lack of actual data to identify problems faced by the poor in the Border; (b) projects that are not needed for the poor in the Border; (c) the categories of target groups that are relevant to the type of project that will be introduced at the Border have not been known.

This research is important because theoretically, any development program, let alone a program on poverty that is directly related to lower class society, besides being difficult, is also problematic. Nor is it because of its multidimensional nature, but it also concerns structural and cultural issues. For this reason, poverty alleviation activities require more complete knowledge and a comprehensive understanding of the map of the existing conditions of the poor. Efforts to know and understand these poverty conditions require socio-economic mapping (social mapping) conducted inductively so as to produce basic data about the real conditions of the community. poor. Based on the basic data on poverty, the root cause of the problem is examined in depth and political and policy science needs to be made in community empowerment models in the form of programs and operational activities that are structured in a participatory manner by and for the poor based on the needs and potential of local communities.

\section{RESEARCH METHODS}

This research was conducted with a qualitative descriptive method with the selection of informants purposively through in-depth interviews to key informants and subsequent informants obtained by snowball. This purposive consideration is the relevance of the informants relevant to the understanding of the condition of the poor and the problems faced in the Border District. This study took the research location in Mahakam Ulu, a new district which was established in 2012 which is a division of Kutai Barat District in East Kalimantan. The choice of location of this study takes into account the existence of factors in the region which is indeed still very far behind in terms of community empowerment especially if compared to cities both in Kalimantan and on Java.

Field observations were made for secondary data collection obtained by observing and documenting the data collected from various related sources, district, sub-district and village governments, the community observing poverty in rural communities, the press and academics. Triangulation of data 
sources is done to obtain data accuracy and is not biased to the interests of certain data sources. Data analysis is done by applying qualitative reduction, selection, exposure and editing to get an objective and quality picture of facts.

\section{DISCUSSION}

\section{Principles of Empowerment}

Village Community Empowerment is an effort to develop community independence and welfare by increasing knowledge, attitudes, skills, behaviors, abilities, awareness, and utilizing resources through the establishment of policies, programs, activities, and assistance that are in line with the essence of the problem and priority needs of the village community (Village Law, Considering paragraph 2).

In an effort to optimize goals and realize the meaning of community empowerment, a principle is needed as a guide or direction for where that goal will be carried out. The principle can also be understood as a view that is a guide or role model for every human behavior in living his life that is historically-empirically viewed as having intrinsic value for him. In the framework of optimizing the processes of strengthening and empowering the community so that they can be independent, prosperous and participatory, with seven basic principles.

First, awareness. The empowerment process must be able to touch cognition of the 'awareness' of something that is seen as unfavorable for the environment and society. Empowerment must be able to arouse, affirm and increase awareness of his position as a whole human being in his environment. Awareness can touch on all fields, namely awareness of politics, awareness of the economy, social awareness and awareness of security and comfort as citizens. Awareness can also involve governance aspects of development and service governance.

The Second is education and training. The empowerment process must be able to improve cognition, affection and psychomotor society. To improve cognition, affection and psychomotor society, the process of education, especially non-formal and training often becomes important. Learning can not only be done through formal schools, but it can be done in non-formal schools to improve community affection and cognition, while improving community psychomotor is often carried out by organizing various types of skills training, such as sewing skills, mortars, salons, people's economic endeavors, etc.

Third, network strengthening. The process of strengthening and empowering communities often fails to meet objectives, because they have never been integrated and synchronized with broader needs. The process of strengthening and empowering the community will be more meaningful, if it is able to be organized and managed in a network context and is cross-sectoral in nature. The more there is and the expansion of networks between organized groups, the empowerment goals will be easy to achieve.

Fourth, the development of strength. The process of political empowerment and empowerment is mainly very much related to efforts to increase and develop the power and power of society together to be able to deal with the tyrannical power or regime pressure, which often squeezes and suppresses and exploits their existence.

Fifth, strengthening social capital. The process of strengthening and empowering the community must be able to accommodate the diversity of existing social values into a power of social capital. The diversity of social values is not interpreted as a seed or a potential for social conflict, but diversity must be placed as an opportunity and strength to build social capital that is more useful and useful. 
Figure 1. Seven Basic Principles of Community Empowerment

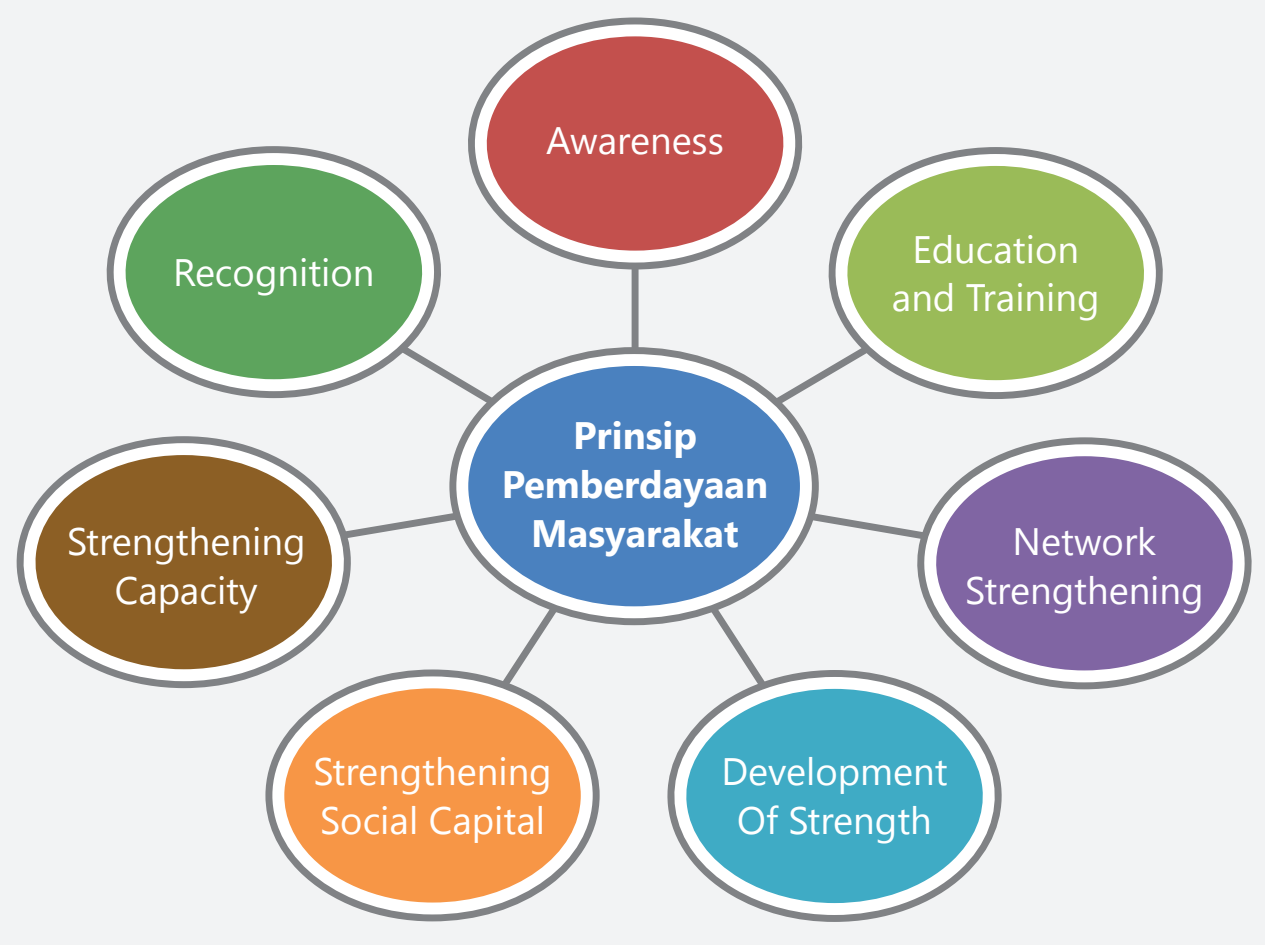

Sixth, strengthening capacity. The process of strengthening and empowering the community must be able to improve the ability of the community to be able to solve and find a way out of a social problem in an integrated and comprehensive manner. The ability of the community here is the ability to understand a problem and find a way out of it from the level of policy, institutions, individuals and also from the community side. And, seventh is recognition. The process of strengthening and empowering the community must be able to realize or give birth to the recognition or existence of society as an independent and autonomous entity.

\section{Village Fund Management for Community Empowerment}

Poverty and underdevelopment are still relatively inherent in the village community. The top-down model development program implemented by the
New Order did not provide a wider opportunity for the village to manage its potential to be independent in improving the welfare of the community. Even though the involvement of the village community by strengthening the role and function of village institutions will open a wide way to solve the problem of poverty and under development.

Attention to village issues began since the reform era was rolled out. The policy of regional autonomy and fiscal decentralization regulated by Law No. 22/1999 and Law No. 25/1999 opened up new hopes for the village and the village community. The expectation is increasingly wide open since it was passed Law No. 32 of 2004 concerning Regional Government and Law No. 33 of 2004 concerning Financial Balance between Central and Regional Governments.

Roles and functions increasingly have great respect and trust when the government establishes special laws governing villages. Law No. 6 of 
2014 concerning Villages gives even greater hope for the empowerment of villages and the welfare of the community. These ideals will be achieved, not only because of the provision of large village funds, but also because of the overall empowerment factor, both in terms of human resources, natural resources and village community institutions.

In article 212 paragraph 3 of Law No. 32/2004 it is clearly specified the village income sources which consist of: native village income, regional tax sharing and district/city regional retribution, part of the central and regional financial balance funds received by the district/city . In addition, the village also received assistance from the government, provincial government and district/city government, as well as grants and donations from third parties.

A special explanation of the balance fund is presented in Article 1 paragraph 11, PP 72/2005. In the article the term Village Fund Allocation or Village Fund Allocation (ADK) was raised which was obtained from the financial balance funds of the central and regional governments received by the district/city. The purpose of the central and regional financial balance funds received by the district/city is the revenue sharing of taxes and natural resources, plus the General Allocation Fund (DAU) after deducting employee expenditure.

According to PP 72/2005 Article 68 (C), the funds shared for the village from the central and regional balance funds received by the regency/ city amount to at least $10 \%$ after deducting personnel expenditure. To divide the amount of ADK distributed to each village two principles were used. First, the equity principle is used so that every village in a district/city has the same village financial capacity. The same size of the Village Fund Allocation for each village is called the Minimal Village Fund Allocation (ADKM). Second, the principle of justice is applied to support every village in managing the potential and constraints or limitations that each village has.
To achieve the principle of justice, the size of the allocation of village funds is calculated based on the village weight value $(\mathrm{BKx})$ with regard to variables such as poverty, affordability, education, health and others. This calculation based on the principle of justice is called the Proportional Village Fund Allocation (ADKP).

The distribution of village funds which has been divided evenly by 90 percent has been reduced by reducing it to 77 percent divided equally and 3 percent specifically for disadvantaged and very disadvantaged villages that have the highest number of poor people. The remaining 20 percent is given based on a new formula for variable population, number of poor people, area size, and level of geographical difficulties. This $20 \%$ increase compared to the old formula which only set aside 10 percent.

Of the four indicators, greater weight is given to the number of poor people to 50 percent. With that change, the villages left behind and the villages were very left behind with a large number of poor people who would get more or less funds with this formula, behind villages would receive village funds of Rp. 864 million and a maximum of Rp. 2.8 billion. The very disadvantaged villages have a minimum of Rp 1.2 billion and a maximum of $\mathrm{Rp} 3.5$ billion.

\section{Potential of Mahakam Ulu}

The villages in the upper Mahakam are mostly close to the forest and even inside the forest itself. Even though they were born and raised in the area around the forest, the community members, especially the village government, were not fully aware of the boundaries between protected forests, production forests and community lands and customary forests. Many incidents of illegal logging are carried out either in production forests or protected forests that are not recognized by the community. On the contrary there are still many 
activities of the state and the community that have not respected the existence of customary forests in the entire Mahakam Ulu district. This problem has the potential to cause conflict, both open and latent, the wood industry and the community about forest use.

The potential of forests in the Mahakam Ulu in addition to the form of hardwood commonly used as building materials also has several other potentials such as gaharu wood which has very high economic value and is sought by many parties. In addition to gaharu wood there are also dammar who have high economic potential, unfortunately until now there have not been any resin collectors so that people use more daily food such as putty/patch boats/ boats rather than being economically cultivated.

The potential of forests that are not less interesting both economically, especially tourism and business development is the diversity of orchid forests in the interior of Kalimantan. The variants of orchids that develop wildly in Mahakam Ulu have not been seriously explored so that product development and market development have not been a concern of the community. Therefore this potential can be developed in the future. In addition to orchids there are still many rare plants including medicinal plants and animals both hunted and can be bred.

Tourism potential in Mahakam Ulu has not yet been developed. Almost every sub-district has objects that can be developed into tourist destinations, especially natural tourism. These potentials include; the beauty of forests and rivers, river rapids, waterfalls, caves, artifacts, and cave tombs. The Mahakam River has an important meaning in the daily life of the people of Mahakam Ulu. The settlement is built around the river and the Mahakam tributary. The community uses the river for transportation routes, and uses natural resources in the river, such as fish, crabs, snails, rocks, sand, and gold.
In terms of human resources (HR), Mahakam Ulu is still far behind the surrounding districts/ cities as a consequence of the relatively young pemekaran regency in East Kalimantan. Teacher's human resources for example, the number of teachers is still lacking so many teachers are forced to teach multiple subjects. In addition, there is also a need to increase teacher competency at various levels of education. The number of teachers from elementary to high school in Long Apari District was 68 people, Long Pahangai District as many as 141 people, Long Laham District as many as 80 people, Long Bagun as many as 150 people and Long Connect as many as 150 people. This number is very unbalanced with the area and the number of schools in the entire Mahakan Ulu Regency.

The number of health workers is also very inadequate, for example 2 doctors in Long Apari District, 2 people in Long Pahangai District, 2 people in Long Laham District, 3 people in Long Bagun and 2 people in Long Hubung. This amount is very unbalanced with the area and health services that should exist throughout the Mahakan Ulu Regency. There are only two dentists, one in Long Pahangai District and one in Long Bagun District. This amount is very unbalanced with the health care needs that should exist throughout the Mahakan Ulu Regency. There are 15 nurses in Long Apari District, 10 people in Long Pahangai District, 4 people in Long Laham District, 3 people in Long Bagun and 20 people in Long Hubung. Midwives in the Long Apari District were 5 people, Long Pahangai District as many as 6 people, Long Laham District as many as 4 people, Long Bagun as many as 10 people and Long Hubung as many as 4 people. 10 TBAs in Long Apari District, 5 people in Long Pahangai District, 6 people in Long Laham District, 11 people in Long Bagun and 11 people in Long Hubung. From the foregoing description, it can be 
seen that health staff and health facilities in each sub-district are still lacking. Each sub-district has a puskesmas, but not all villages have a SubDistrict Health Center (Pustu). Not all villages have midwife work, so the delivery process is supported by dukun beranak which generally exists in every village.

Agriculture develops lading agriculture which is the work of the majority of the population in almost all villages. Besides gardening activities and becoming collectors from the surrounding forest. Rice farming activities have not developed even though they have been developed before. Paddy farmers have not developed, due to habitual problems and have not mastered the technique of rice cultivation. In addition, the presence of irrigation networks is also still limited. In the 80 s, open a rice field, around 50 ha, had twice been planted. Sawah is there, but it is not managed. Problems faced: Unaccustomed to paddy patterns, poor formation, no irrigation channels and In Datah Bilang Village, there are irrigation channels, but the water does not reach the paddy fields because the rice fields are higher. In the Mahakam Ulu, cocoa (brown) is also very potential to be cultivated, but the results are not too optimal because the farmers do not understand the problem of pests and their handling and the spacing is not standard. In addition, farmers also face quality problems because they are still using local seeds and poor marketing guarantees. In almost every village there are actually PPLs, but it turns out that they do not work well and even rarely provide counseling to farmers.

Rubber is also a good commodity, the prospect is in Mahakam Ulu. Even though the rubber in Mahakam Ulu is a superior type of rubber, it turns out there are many obstacles in its cultivation. The problem that many face is the lack of technology controlled by farmers so that the resulting rubber is of low quality so the price is also low or even uncertain in addition to marketing it is indeed constrained by relatively difficult transportation which is absorbed in transport costs.

\section{Empowering Villages Through Good Governance}

The management of good and right governance is the hope of all parties. In the village area (or in Ulum Mahakam better known as kampung), the head of village has a large role, function and responsibility to make it happen. The head of village who are democratically elected, can no longer work with only orders, because what is needed is the ability to generate maximum participation from components in the village.

Social institutions which are the place for gathering social communities in the village, such as fishermen groups, teacher groups, small and medium entrepreneurs groups and other groups cannot be left behind in managing the village. The role of village institutions can be a political representation of the villagers, so playing them in creating a clean and good government is absolutely necessary.

Village institutions which according to the law are representative of the people and have an equal position to the the head of village in the village administration are the Village Consultative Body (Badan Permusyawaratan Kampung/BPK). The BPK institution, as a the head of village partner, has a strategic role to organize good governance so that the development goals to reduce poverty and improve people's welfare can be achieved.

The involvement of many parties in managing village governance must be based on the principles of transparency, accountability, participation and others. All of that is needed so that in managing the organizational structure, compiling regulations, arranging financial planning and accountability can really achieve good governance. 1) Shifting the Role and Function of Village Consultative Bodies (BPK).. 
Since the current reform era, the duties, functions and position of the Village Consultative Body (BPK) have undergone several changes. These changes follow regulations made by the government. The first change was made based on Law No. 22/1999 on Regional Government. In the law the BPK is still interpreted as a Village Representative Body that functions as a village legislature. The second change is based on Law No. 32/2004. The BPK according to the law on Regional Government was changed to mean the Village Consultative Body which functioned as the organizer of the village government together with the the head of village.

The function of the BPK based on Law No. $6 / 2014$ was shifted into a village institution that carried out government functions and did not play a role as a government organizer. The changes in the roles and functions of the BPK are based on the desire to accelerate the realization of autonomous and independent villages through the administration of good governance. From this professional governance management, it is expected to be able to improve the welfare of the community and reduce poverty. This expectation can be achieved if there is a harmonious cooperative relationship between the BPK and the The head of village.

Formulating BPK's relationship with the Head of the Village so that the two institutions run harmoniously and not drop each other is not easy. If strengthening the position of the BPK will result in the position of the Head of the Village becoming weaker, as happened in the implementation of Law No. 22/1999. Strengthening the functions of the BPK was revised through Law No. 32/2004 concerning Regional Government. In the law, the authority possessed by the BPK as well as being a regulator of the The head of village, is also expected to function as a control institution that carries out checks and balances.

In Law No. 23/2004 concerning Regional
Government, the BPK was included as the organizer of the government with the Head of the Village. The decree was intended to reduce the conflict of interest between the two village administration organizers. But BPK's participation in regulating and making village decisions made the BPK's legal function very strong, as stipulated in article 209 of the Village Law which reads, "The Village Consultative Body functions to establish village regulations with the the head of village, to accommodate and channel people's aspirations".

Deliberation is a people's democratic space that differentiates from democracy that applies in other countries. The heart of Pancasila democracy is deliberation to accommodate and fight for the will of the people as stated in the fourth principle of the Pancasila. The organizer of the meeting in the village is the BPK which has the right to invite the heads of government, village institutions, and community leaders to discuss village issues, accommodate creative ideas and to ask for information from the the head of village about development, budget use, poverty alleviation programs and so on.

Deliberation is the main task of the BPK in accordance with Article 1 paragraph (5). In the article it was stated that the Village Consultation or what was referred to by another name was a discussion between the BPK, the Kampung Government, and community elements organized by the BPK to agree on strategic matters. Strategic matters are explained in the Village Law Article 54 (paragraph 2), relating to:
a. Village arrangement.
b. Village planning.
c. Village cooperation.
d. Investment plan that goes into the village.
e. Establishment of BUM Desa.
f. Addition and release of village assets.
g. Extraordinary event.

By acting as organizers of the deliberations, 
the BPK in accordance with its name 'Kampung Consultative Body', democratization in the village is expected to be a strong capital for the community to create a village. Independent villages will strengthen the joints of the economy, politics and social culture and resilience. Thus, the main village meeting was to make the village the subject of development.

Massive changes occurred in the village after Law No. 6 of 2014 was passed. Articles that discuss authority, management of village government, financial and asset management, capacity building of human resources, strengthening village institutions open wide opportunities so that villages can become independent, carry out their own development programs by utilizing the maximum potential available in good villages. in the form of human resources and natural resources.

The new village which was rolled out through the Village Law made the villagers no longer lose their rights to regulate their own households. Community demands on the needs of various fields of development which so far have not been able to be channeled, now with the Village Law, all aspirations and citizen participation are recognized and responded positively by the village government, BPK and village institutions. The role of the village government, and the BPK that has strategic duties and functions will realize the demands of the community as a village program aimed at increasing welfare and reducing poverty.

Article 72 of Law No. 6 of 2014 can be called a rule that revolutionizes the village from its position as the object of development to be the subject of development. Article that obliges the government to channel direct balancing funds to villages with a new formula, namely 77: 3: 20 giving full authority to the village government together with the Village Consultative Body and village institutions to develop a program of activities needed by the villagers.
The use of village funds proposed by villagers for the interests of the village is a real democratization that has grown and developed since the formation of the village as a legal entity recognized by law. The the head of village chosen by the people through the election of a democratic the head of village will be a symbol of the village power to carry out development work that stands on his own feet. The appreciation of the village grew after the BPK functioned as an institution that had the role of organizer of deliberation to accommodate, solve and explore the potential of the village so that the economy grew rapidly to prosper and prosper the villagers.

Law No. 6 of 2014 is actually not a matter of the most important transfer of balance funds, because community empowerment that is expected to participate is a more important issue in the village law. The development process that grows from the grassroots is more appropriately applied to accelerate poverty alleviation and abandon underdevelopment.

The development experience of the New Order era which was more powerful in applying the top down model proved to be very slow in advancing the village as the frontline of development. Crossministerial programs that were handed down to the villages were instructive without dialogue, without involving many people, they failed.

The trust given by the government to the village community, village government, BPK and village institutions in the form of giving up some of the affairs will ease the burden on the central, provincial and district / city governments while at the same time encouraging a higher spirit of village independence. Through increasing human resource capacity and optimal use of natural resources and strengthening village institutions, all village development programs starting from the selection of activities, planning, implementation and monitoring and evaluation were moved from 
the village, by the village and to the village.

Before the Village Law was enacted, the village was still seen as an object of mere development. As an object, villages are only made part of sectoral programs. Sometimes programs that come to the village from the government do not meet the needs of the community. The Village Law, which has been approved by the House of Representatives together with the government, has recognized the village as a unit of the legal community and an independent set of independent sociopolitical-cultural entities. Thus, the village community should be empowered to become the real development actors.

As the subject of development, the Village Law, Government Regulations, Ministerial Regulations (Ministry of Home Affairs, Ministry of Village, and Ministry of Finance) offer regulations that give full authority to village governments to create, initiate and realize all programs in real action. From an economic standpoint, to raise the potential of local villages can be established VillageOwned Business Entity as an effort to improve the welfare of citizens.

\section{CONCLUSION}

Analysis of the conditions of existence of the Border District and the environmental conditions of the policy at the provincial, national and international levels to find the root of the problem of the helplessness of the Border community. The root of the problem of community helplessness is more dominant due to the physical condition and infrastructure, the socio-cultural and economic conditions of the Border District. From these conditions it was found the need for several strategic efforts to encourage community empowerment through: a) Increasing the quantity and quality of road, bridge and agricultural infrastructure, b) Increasing competitive and competitive agricultural productivity by developing organicbased agricultural industries, c) Improving the quality of human resources by improving health and education services, d) Decreasing unemployment by improving the business climate in the context of creating new entrepreneurs, e) Increasing regional economy by developing superior regions-based sectors, f) Increased access and means of transportation of residents and goods between regions in the Border District, g) Improved governance to support excellent service to the community.

Community perceptions of community empowerment are needed in an effort to encourage participatory community empowerment planning which is carried out in the following participatory steps: Socialization of Village Laws, Asset Analysis and Local Village Potential, Preparation of Village Development Mapping and Plan Results, and Establishment of Development Working Groups Village Assets. Participatory planning in community empowerment produces several objectives as follows: A common understanding of the contents of the Village Law. Thus, an understanding of the Village Law can be comprehensive and touch on substantive matters, not limited to the amount of village fund receipts. After that, between the village government, all community institutions in the village, and the community can look back on the village planning that has been made and running. Approach to the potential and strength of the village, supported by active community participation, is expected to appear more appreciative planning with its own strength. welfare indicators determined from the village become a guide in village development planning that is able to touch the fulfillment of basic needs. This local potential based village development plan and carried out in a participatory manner will become a reference for the village government in implementing 
development. That way, village planning can fulfill basic service access and prosperity for residents. Village asset development working group formed through workshops involving all stakeholders in the village. encourage transparent and accountable governance.

The community empowerment model that is in accordance with the aspirations of the community while adopting village development institutional regulations is organized in the following activities:

a) Village arrangement, b) Village planning, c) Village cooperation, d) Investment plans that enter the village, e) Establishment of BUM Village, f) Addition and release of village assets.

Poverty and underdevelopment are still relatively inherent in the village community. The top-down model development program implemented by the New Order did not provide a wider opportunity for the village to manage its potential to be independent in improving the welfare of the community. Even though the involvement of the village community by strengthening the role and function of village institutions will open a wide way to solve the problem of poverty and underdevelopment.

Attention to village issues began since the reform era was rolled out. The policy of regional autonomy and fiscal decentralization regulated by Law No. 22/1999 and Law No. 25/1999 opened up new hopes for the village and the village community. The expectation is increasingly wide open since it was passed Law No. 32 of 2004 concerning Regional Government and Law No. 33 of 2004 concerning Financial Balance between Central and Regional Governments.

Roles and functions increasingly have great respect and trust when the government establishes special laws governing villages. Law No. 6 of 2014 concerning Villages gives even greater hope for the empowerment of villages and the welfare of the community. These ideals will be achieved, not only because of the provision of large village funds, but also because of the overall empowerment factor, both in terms of human resources, natural resources and village community institutions.

\section{REFERENCES}

Arze, F. J., Martinez-vazquez, J., \& Mcnab, R. M. (2016). Decentralized Governance, Expenditure Composition, and Preferences for Public Goods. Public Finance Review, 1(30), 1-30. https://doi.org/10.1177/1091142116639127

Bannister, F., \& Connolly, R. (2012). Defining e-Governance. E-Service Journal, 8(2), 3-25.

Boelens, L., \& Roo, G. De. (2016). Planning of undefined becoming: First encounters of planners beyond the plan. Planning Theory, 15(1), 42-67. https://doi.org/10.1177/ 1473095214542631

Bryant, Carolie \& White, L.G, 1982, Managing Development in The Third World, Westview Press, I Boulder, Colorado.

Cadman, T. (2012). Evaluating the Quality and Legitimacy of Global Governance: A Theoretical and Analytical Approach. The International Journal of Social Quality, 2(1), 4-23. https://doi.org/10.3167/IJSQ. 2012.020102

Chaskin, R. J., \& Greenberg, D. M. (2015). Between Public and Private Action: Neighborhood Organizations and Local Governance. Nonprofit and Voluntary Sector Quarterly, 44(2). https://doi.org/10.1177/ 0899764013510407

Dunn, William, 1995, Analisa Kebijaksanaan Publik, Hanindita Offset, Yogyakarta.

-------------------, 1999, Pengantar Analisa Kebijakan Publik, Gadjah Mada University Press, Yogyakarta.

Dye, Thomas, R., 1966, Politics, Economics and the Publics : Policy Outcomes in The Fifty States, Rand-Mc Nally, Chicago. 1995, Understanding Public Policy, Prentice Hall, New Jersey. El-Rashidi, F, 1971, Human Aspecs of Development, IIAS, Brussels.

Enroth, H. (2014). Governance: The art of 
governing after governmentality. European Journal of Social Theory, 17(1), 60-76. https://doi.org/10.1177/1368431013491818

Healey, P. (2003). Collaborative planning. Planning Theory, 2(2), 101-123.

Heilmann, S., \& Melton, O. (2013). The Reinvention of Development Planning in. Modern China, $39(6)$. https://doi.org/10.1177/ 0097700413497551

Hudson, C. (2013). Governing the Governance of Education: the state strikes back? European Educational Research Journal, 6(3), 266-282.

Islamy, Irfan, M., 1997, Prinsip-Prinsip Perumusan Kebijakan Negara, Bumi Aksara, Jakarta.

Khan, M. M., \& Islam, M. S. (2014). Democracy and Good Governance in Bangladesh: Are They Compatible? Millennial Asia, 5(1), 23-40. https://doi.org/10.1177/ 0976399613518855

Loftin, M. K. (2018). Truths and governance for adaptive management. Ecology and Society, 19(2).

Moleong, Lexy J, (1991), Metodologi Penelitian Kualitatif, Cetakan Ketiga, PT Remaja Rosdakarya, Bandung.

Platzdasch, B. (2012). INDONESIA IN 2010: Moving on from the Democratic Honeymoon. Southeast Asian Affairs, (11), 73-90.

Soeprapto, Riyadi, 2000, Evaluasi Kebijakan Publik, UM Press, Malang.

Teles, F. (2012). Local Governance, Identity and Social Capital: A Framework for Administrative Reform. Theoretical and Empirical Researches in Urban Management, 7(4), 20-34.

Truman, David, 1951, The Govermental Process, Knopf, New York.

Wibawa, S., 1994, Evaluasi Kebijakan Publik, PT Raja Grafindo, Jakarta

Worboys, G. L., Lockwood, M., Kothari, A., Feary, S., \& Pulsford, I. (2015). PLANNING: Protected Area Governance and Management. Canberra: ANU Press. Retrieved from http://www.jstor.org/stable/j.ctt1657v5d.20 